\title{
Kajian Jarak Aman Antara Arrival Traffic dan Departure Traffic Pada Unit Aerodrome Control Tower di Perum LPPNPI Kantor Cabang Pontianak
}

\author{
Daniel Dewantoro R*, Zinat Tamami, Endang Sugih Arti, Pangsa Rizkina Aswia \\ Politeknik Penerbangan Indonesia Curug, Tangerang. \\ *daniel.dewantoro@ppicurug.ac.id
}

\begin{abstract}
Supadio International Airport is an airport that serves various types of aircraft (Boeing, Airbus, ATR, Hawk, CN259), and does not have a rapid exit taxiway, in its guidance, Perum LPPNPI Pontianak Branch Office enforces rules for Boeing and Airbus-type arrival traffic for backtrack at the end of the runway, but this rule does not apply to aircraft with other types such as ATR and Cessna. This of course creates a time difference to clear the runway for arrival traffic of the Airbus and Boeing types. This study aims to obtain a safe distance between arrival traffic and departure traffic at the Perum LPPNPI Pontianak Branch Office by applying the calculation of The Brazilian Air Navigation Management Center (CGNA) Runway Capacity Calculation by adjusting the current airport conditions. From the research results, it is found that the value of the safe distance between arrival traffic and departure traffic by considering the aircraft classification can produce a more optimal safe distance.
\end{abstract}

Keyword: runway occupancy time, safety separation.

\section{PENDAHULUAN}

Transportasi udara adalah salah satu moda yang paling cocok dengan kondisi geografis Indonesia yang merupakan negara kepulauan. Setiap orang mampu berpindah dari satu pulau ke pulau lain hanya dengan menghabiskan waktu yang relatif cepat. Sejak dikeluarkannya Keputusan Presiden Nomor 33 Tahun 2000 yang berarti Pemerintah melonggarkan peraturan mengenai regulasi penerbangan yang memicu tumbuhnya jumlah penumpang disertai dengan maskapai penerbangan baru (Tiarto and Rumani 2020). Mengakibatkan bertambahnya permintaan jasa penerbangan yang harus disertai dengan peningkatan faktor keselamatan penerbangan. Keselamatan merupakan hal yang harus diutamakan dalam dunia penerbangan. Untuk menciptakan keselamatan penerbangan, maka dibentuklah pelayanan pemandu lalu lintas udara yang disebut dengan Air Traffic Controler (ATC) atau pemandu lalu lintas udara. Selain menjaga keselamatan penerbangan seorang pemandu lalu lintas udara juga memiliki tugas untuk dapat mengarahkan pesawat secara efisien sehingga tercipta operasi penerbangan yang aman, lancar, teratur dan cepat. Sesuai dengan Annex 11 Air Traffic Services Chapter 2.2.2 Point 3 dan 4 (2018) memperlancar arus lalu lintas udara serta memberikan saran dan informasi yang berguna untuk pelaksanaan penerbangan yang aman dan efisien. 
Salah satu faktor yang dapat menciptakan operasi penerbangan yang efisien pada aerodrome control service adalah menerapkan jarak aman yang optimal antara arrival traffic dan departure traffic. Selain itu dengan menerapkan jarak aman antara arrival traffic dan departure traffic yang optimal dapat menimbulkan keuntungan bagi Perum LPPNPI Kantor Cabang Pontianak yaitu dengan meminimalkan terjadinya delay sehingga meningkatkan kualitas pelayalanan, dan meningkatkan kapasitas runway. Bandar Udara Internasional Supadio adalah sebuah bandar udara yang memiliki 1 runway, 2 apron dan 6 taxiway yaitu taxiway Alpha, Bravo, Charlie, Delta, Echo dan Foxtrot (tidak memiliki rapid exit taxiway), yang melayani berbagai macam type pesawat (Boeing, Airbus, ATR, Hawk, CN259). Dimana Perum LPPNPI Kantor cabang Pontianak dalam pemanduannya memberlakukan aturan untuk arrival traffic yang memiliki type Boeing dan Airbus untuk back track at the end of the runway, tetapi peraturan ini tidak berlaku untuk pesawat dengan type yang lain seperti ATR dan Cessna. Hal ini tentunya menimbulkan perbedaan waktu untuk mengosongkan runway bagi arrival traffic bertype Airbus dan Boeing. Berdasarkan Standard Operation Procedure yang dijadikan sebagai acuan kerja air traffic controller, jarak aman yang berlaku saat ini tidak optimal dikarenakan jarak aman yang berlaku di berlakukan untuk seluruh type pesawat baik itu pesawat yang membutuhkan waktu tambahan untuk mengosongkan runway maupun pesawat yang tidak membutuhkan waktu untuk mengosongkan runway, sehingga pelayanan pemanduan lalu lintas yang di berikan tidak efisien.

\section{METODE PENELITIAN}

Dalam penelitian ini, peneliti menggunakan metode penelitian kuantitatif, adapun metode pengumpulan data yang digunakan ialah observasi lapangan dan studi dokumentasi.

\subsection{Metode Pengumpulan Data}

Dalam penelitian ini, peneliti menggunakan beberapa teknik pengumpulan data, yaitu :

1. Observasi Lapangan

Observasi adalah kegiatan untuk melakukan pengukuran atau pencatatan data dimana peneliti tidak mengajukan pertanyaan melainkan melalui panca indera (Aminarno:2019). Pesawat yang sedang beroperasi digunakan sebagai objek utama pengamatan. Adapun data yang dibutuhkan melalui observasi ialah data Runway Occupancy Time Departure dan data Runway Occupancy Time Arrival.

2. Studi dokumentasi

Dalam penelitian ini, peneliti melakukan teknik pengumpulan data dan informasi melalui dokumen- dokumen ICAO dan AirNav Indonesia. Dimana hasil data dari studi dokumentasi peneliti gunakan sebagai data primer.

\subsection{Metode Analisis Data}

Teknik analisis data yang digunakan oleh peneliti adalah dengan menerapkan perhitungan The Brazilian Air Navigation Management Center (CGNA) Runway Capacity Calculation dengan penyesuaian kondisi lapangan saat ini.

Adapun langkah-langkah perhitungan dalam penelitian ini ialah : 


\section{Langkah1 :}

Pengumpulan data Runway occupancy time (ROT) ketika take off (ROTT) dan landing (ROTL).

\section{Langkah 2 :}

Menghitung rata-rata waktu runway occupancy time untuk setiap klasifikasi pesawat.

\section{Langkah 3 :}

Menghitung flight time dari PNK sampai threshold runway 15. Nilai flight time diperoleh dengan menggunakan rumus kecepatan, jarak dan waktu. Dimana data jarak di peroleh dari Aeronautical Information Publication (AIP) Indonesia dan data kecepatan di peroleh dari data IAS (indicator airspeed) dalam Doc 8168 PANS OPS Part I-Section 4, Table I-4-1-2 Speeds (IAS) for procedure calculations in knots (kt). Kemudian data IAS dikalikan dengan conversion factor ISA +15 sehingga mendapatkan nilai TAS (true air speed). Nilai TAS yang di peroleh di tambahkan dengan tail wind factor sebesar 10 knot sesuai dengan ketentuan yang ada pada Doc 8168. Hasil dari penjumlahan ini yang kemudian dijadikan data untuk mencari waktu.

\section{Langkah 4}

Mencari data final approach speed dimana kecepatan yang digunakan adalah nilai TAS $+10 \mathrm{kt}$.

\section{Langkah 5}

Menghitung besar nilai dari safety separation. Dengan cara nilai dari average runway occupation time di bandingkan dengan nilai dari flight time from PNK to the threshold runway 15. untuk menentukan jarak aman (Safety separation/SS). Safety separation dimaksud adalah jarak aman untuk memberikan ijin 1 pesawat untuk take- off diantara 2 consecutive landing.

\section{HASIL DAN PEMBAHASAN}

Tabel 1. Hasil yang diperoleh berdasarkan perhitungan data ROTD runway15.

\begin{tabular}{|c|c|c|c|c|c|c|c|c|c|}
\hline \multirow{2}{*}{ Cat } & \multicolumn{10}{|c|}{ Taxiway (t) } \\
\cline { 2 - 11 } & Alpha & $\mathrm{n}$ & $\mathrm{x}$ & $\begin{array}{c}\text { Brav } \\
\mathrm{o}\end{array}$ & $\mathrm{n}$ & $\mathrm{x}$ & $\begin{array}{c}\text { Charli } \\
\mathrm{e}\end{array}$ & $\mathrm{n}$ & $\mathrm{x}$ \\
\hline B & 60 & 1 & 60 & - & - & & - & - & \\
\hline C & 780 & 12 & 65 & 780 & 8 & 98 & - & - & \\
\hline D & 1620 & 14 & 116 & 2100 & 17 & 124 & 3960 & 29 & 137 \\
\hline
\end{tabular}

Tabel 2. Hasil yang diperoleh berdasarkan perhitungan data ROTA runway15.

\begin{tabular}{|l|l|l|l|l|l|l|l|l|l|}
\hline \multirow{2}{*}{ Cat } & \multicolumn{10}{|c|}{ Taxiway (t) } \\
\cline { 2 - 11 } & Alpha & $\mathrm{n}$ & $\mathrm{x}$ & Bravo & $\mathrm{n}$ & $\mathrm{x}$ & Charlie & $\mathrm{n}$ & $\mathrm{x}$ \\
\hline B & 60 & 1 & 60 & - & - & & - & - & - \\
\hline C & - & - & - & 1560 & 10 & 156 & 1380 & 14 & 99 \\
\hline D & - & - & - & 1020 & 5 & 204 & 10080 & 55 & 184 \\
\hline
\end{tabular}

Rata-rata Runway Occupancy Time di dapat dari penjumlahan ROTD t1 dan ROTA yang di jumlahkan berdasarkan klasifikasi pesawat kemudian hasilnya di bagi 2 kemudian ditambah nilai t2, adapun hasil dari perhitungannya dapat dilihat pada tabel di bawah ini. 
Tabel 3. AROT departure via taxiway alpha

\begin{tabular}{|c|c|c|c|r|r|}
\hline Cat & IAS & $\begin{array}{c}\text { Conversi } \\
\text { onfactor }\end{array}$ & TAS & $\begin{array}{r}\text { TAS }+ \\
10 \mathrm{kt}\end{array}$ & $\begin{array}{r}\text { TAS* } \\
(\mathrm{m} / \mathrm{s})\end{array}$ \\
\hline B & 130 & 1,0567 & 137,37 & 147,37 & 75,81 \\
\hline C & 160 & 1,0567 & 169,07 & 179,07 & 92,12 \\
\hline D & 185 & 1,0567 & 195,49 & 205,49 & 106,11 \\
\hline
\end{tabular}

Tabel 4. AROT departure via taxiway bravo.

\begin{tabular}{|c|c|c|c|c|c|c|}
\hline \multirow{2}{*}{ X } & \multicolumn{3}{|c|}{ AROT } & \multicolumn{3}{c|}{ AROT + t2 } \\
\cline { 2 - 7 } & B & C & D & B & C & D \\
\hline B & 60 & 63 & 88 & 120 & 123 & 148 \\
\hline C & 108 & 111 & 136 & 168 & 171 & 196 \\
\hline D & 132 & 135 & 160 & 192 & 195 & 220 \\
\hline
\end{tabular}

Tabel 5. AROT departure via taxiway chaarlie.

\begin{tabular}{|c|c|c|c|c|}
\hline \multirow{2}{*}{$X$} & \multicolumn{2}{|c|}{ AROT } & \multicolumn{2}{c|}{ AROT + t2 } \\
\cline { 2 - 5 } & C & D & C & D \\
\hline B & 79 & 92 & 139 & 152 \\
\hline C & 127 & 140 & 187 & 200 \\
\hline D & 151 & 164 & 211 & 224 \\
\hline
\end{tabular}

Tabel 6. Kecepatan pesawat dari PNKto the intial approach fix.

\begin{tabular}{|c|c|c|c|r|r|}
\hline Cat & IAS & $\begin{array}{c}\text { Conversi } \\
\text { on factor }\end{array}$ & TAS & $\begin{array}{r}\text { TAS }+ \\
10 \mathrm{kt}\end{array}$ & $\begin{array}{r}\text { TAS }^{*} \\
(\mathrm{~m} / \mathrm{s})\end{array}$ \\
\hline B & 180 & 1,0567 & 190,21 & 200,21 & 102,99 \\
\hline C & 240 & 1,0567 & 253,61 & 263,61 & 135,61 \\
\hline D & 250 & 1,0567 & 264,18 & 274,18 & 141,04 \\
\hline
\end{tabular}

Tabel 7. Kecepatan pesawat dari intial approach fix to the final approach fix

\begin{tabular}{|c|c|c|}
\hline \multirow{2}{*}{$X$} & AROT & AROT $+\mathrm{t} 2$ \\
\cline { 2 - 3 } & D & D \\
\hline B & 99 & 159 \\
\hline C & 147 & 207 \\
\hline$D$ & 171 & 231 \\
\hline
\end{tabular}

Langkah berikutnya adalah menghitung flight time dari PNK sampai threshold runway15. Dengan cara mencari kecepatan pesawat terlebih dahulu. Kecepatan pesawat dari PNK sampai threshold runway15 berbeda berdasarkan segmen yang dilaluinya, dalam kasus Bandar Udara Internasional Supadio segmen tersebut dibagi menjadi sebagai berikut :

a) Kecepatan pesawat dari PNK sampai initial approach fix (initial approach segment);

b) Kecepatan pesawat dari initial approach fix sampai final approach fix (initial 
approach segment);dan

c) Kecepatan pesawat dari final approach fix sampai threshold runway 15 (initial approach segment).

Adapun proses perhitungan Flight time dari PNK sampai threshold runway 15 di sajikan pada tabel dibawah ini.

Tabel 8. Kecepatan pesawat dari final approach fix to the threshold runway 15

\begin{tabular}{|c|c|c|c|c|c|}
\hline Cat & IAS & $\begin{array}{c}\text { Conversi } \\
\text { onfactor }\end{array}$ & TAS & $\begin{array}{c}\text { TAS }+ \\
10 \mathrm{kt}\end{array}$ & $\begin{array}{c}\text { TAS* } \\
(\mathrm{m} / \mathrm{s})\end{array}$ \\
\hline B & 130 & 1,0257 & 133,34 & 143,34 & 73,74 \\
\hline C & 160 & 1,0257 & 164,11 & 174,11 & 89,57 \\
\hline D & 185 & 1,0257 & 189,75 & 199,75 & 102,8 \\
\hline
\end{tabular}

Selanjutnya dengan menggunakan rumus kecepatan, jarak dan waktu maka didapatlah nilai dari flight time dari PNK sampai threshold runway 15.

Tabel 9. flight time dari PNK sampai threshold runway 15.

\begin{tabular}{|l|l|l|l|l|l|}
\hline Cat & $\begin{array}{c}\text { PNK - } \\
\text { IF }\end{array}$ & $\begin{array}{c}\text { IF- } \\
\text { FAF }\end{array}$ & $\begin{array}{c}\text { FAF - } \\
\text { THR }\end{array}$ & Total & \multicolumn{1}{|c|}{ Total $^{*}$} \\
\hline B & 179,81 & 65,96 & 153,90 & 399,67 & $6 \mathrm{mnt} 30 \mathrm{~s}$ \\
\hline C & 136,57 & 54,28 & 126,65 & 317,5 & $5 \mathrm{mnt} 10 \mathrm{~s}$ \\
\hline D & 131,3 & 47,30 & 110,37 & 288,97 & $4 \mathrm{mnt} 40 \mathrm{~s}$ \\
\hline
\end{tabular}

Langkah terakhir yaitu mencari nilai dari safety separationi yaitu dengan cara nilai dari average runway occupation time dibandingkan dengan nilai dari flight time from PNK to the threshold runway15.

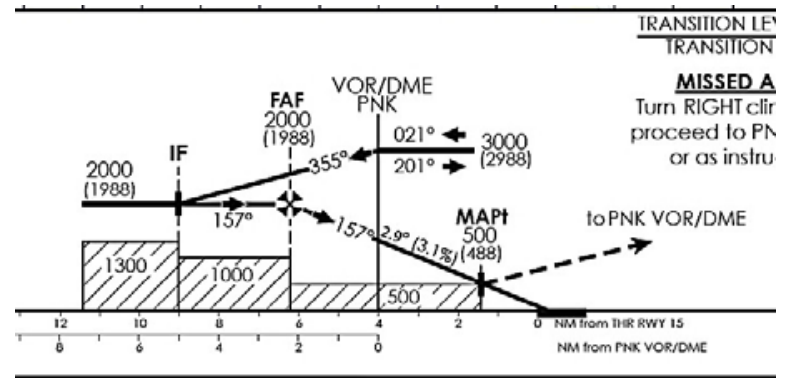

Gambar 1. Ilustrasi posisi pesawat arrival

Data dari tabel 9 dan waktu AROT di bandingkan dengan posisi pesawat arrival pada gambar 1. Sisa dari waktu AROT pada segmen di ubah menjadi jarak, dengan menggunakan rumus kecepatan, jarak dan waktu dimana kecepatan disesuaikan dengan klasifikasi pesawat dan posisi pesawat pada saat itu.

\begin{tabular}{|c|c|c|c|c|c|}
\hline \multirow{2}{*}{$\mathrm{X}$} & \multicolumn{5}{|c|}{ Safety separation (Nm) } \\
\cline { 2 - 6 } & \multicolumn{2}{|c|}{$\begin{array}{c}\text { Dep } \\
\text { Alpha }\end{array}$} & \multicolumn{2}{c|}{$\begin{array}{c}\text { Dep } \\
\text { Bravo }\end{array}$} & $\begin{array}{c}\text { Dep } \\
\text { Charlie }\end{array}$ \\
\cline { 2 - 6 } & B/C & D & C & D & D \\
\hline B & 5 & 6 & 6 & 7 & 7 \\
\hline C & 9 & 11 & 10 & 11 & 11 \\
\hline D & 12 & 14 & 13 & 14 & 15 \\
\hline
\end{tabular}




\section{KESIMPULAN}

Kesimpulan dari penelitian ini ialah besar nilai jarak aman antara arrival traffic dan departure traffic dengan memperhatikan klasifikasi pesawat dapat menghasilkan jarak aman yang lebih optimal.

\section{DAFTAR PUSTAKA}

Amendment Service to the Aeronautical Infornation Publication (AIP AMDT), AIP AMDT Indonesia Volume II, Juli 2018.

International Civil Aviation Organization. Doc. 9426-AN/924 Air Traffic Service Planning Manual.1984.

International Civil Aviation Organization. Doc 8168 OPS/611 Aircraft Operations.2006.

International Civil Aviation Organization. SAM/IG/4 WP/35. Runway Capacity Calculation The Brazilian Air Navigation Management Center (CGNA) 83- 118.2009.

International Civil Aviation Organization. Annex 11 Air Traffic Services.2018.

Organization, International Civil Aviation. Doc 4444 Air Traffic Management. 16th edition. 2016.

Pradana, Aminarno Budi. Metodologi Penelitian Ilmiah. Sekolah Tinggi Penerbangan Indonesia. 2019.

Tiarto, and Daniel D. Rumani. Enhance Airlines Deregulation Technique Commercial Air Transport Schedule Indonesia. 2020. 